DOI: 10.11649/a.1431

Article No.: 1431

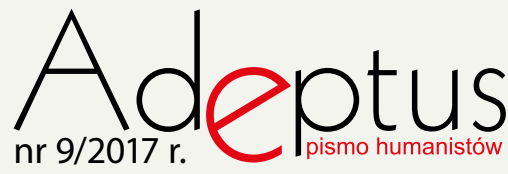

Małgorzata Kot - a PhD candidate in sociology at the Graduate School for Social Research at the Institute of Philosophy and Sociology of the Polish Academy of Sciences. She's interested in queer theories, nonheteronormative kinships and families. Her doctoral thesis is focused on mothering among nonheteronormative female couples in Poland.

e-mail: malgokot88@gmail.com

Małgorzata Kot

\title{
From assimilation, through transformation to studies within relationships: Understandings of nonheteronormative motherhood and ways forward
}

|

$\mathrm{n}$ the recent decades, motherhood beyond heteronormativity has been taken into consideration by many researchers, who have challenged the institution of motherhood as patriarchal and have aimed to transform definitions of and perspectives on parenting, relationships, identities and kinships. The concepts of motherhood itself have been destabilized as well, beginning with Adrienne Rich's approach to motherhood as oppression, institution, normativity versus experience, agency, autonomy, developed in Of Woman Born (Rich, 1976). Adrienne Rich challenged the representation of mothers as passive and identical objects and paid attention to their self-agency (Springgay \& Freedman, 2012, p. 3). This transformation of motherhood into agency, along with addressing nonheterosexual identities and relationships, opened the path to studies of mothering which takes place in nonheteronormative kinships, at the same time being exposed to and tackling the heteronormative patterns. In this article I would like to follow the paths taken so far in studies on particularly lesbian motherhood and explore what strategies have been predominant. I also aim to propose the frameworks of Braidotti's nomadic subjectivity and Deleuze's becoming as useful guides for thinking about and analysing nonheteronormative mothering. I argue that through the usage of these concepts a research of nonheteronormative mothering 
is able to show ways out of the trap of assimilation/transformation and essentialization of nonheteronormative mothers' identities and practices.

\section{Just the same, similar or different? Understandings of nonheterosexual-headed families}

Sociocultural and political changes regarding the recognition of LGBTQ persons and acknowledgement of their rights, as well as new methods of reproduction enabled female partners to decide together whether and how to have a child. Although it might seem that these opportunities lead to more openness towards nonheteronormative mothering, the heteronormative scripts, patterns of motherhood had (and still do have) a strong position. Motherhood inscribes social, cultural and political meanings on women's bodies; the script which dictates how a mother should behave, nurture, express affects towards the child (O'Reilly, 2004, p. 6). The women who decided to become mothers through adoption, extended-family constellation, or in a nonheterosexual relationship, need to additionally prove their mastery to be recognized as legitimate mothers. The heteronormative world dictates the requirements; after fulfilling them one might argue oneself to be a mother. All mothers who go beyond the normativity might at best try to aspire to being a mother as if a real one by following closely the mother script. Taking into account lesbian mothers specifically, a lesbian cannot be thought to be a mother, as the "breeder" that is the mother cannot be queer. A queer mother is thus an oxymoron, able to find its space neither in motherhood, nor in the queer world (Thompson, 2002, p. 6). One of the researchers who aimed to bring motherhood and queer theory closer is Shelley M. Park, who took into consideration adoptive, lesbian, polygamous and blended families, demonstrating how the predominant discourses include some mothers and excluding others based upon the concepts of real motherhood (Park, 2013, p. 78). Strategies employed within the heteronormative world - deriding, degrading, claiming polymaternal families as unreal, impossible - all serve to minimize their importance and sense of their existence, to discipline disobedient bodies and subjects. What Park also rightly pays attention to is the interlinkage between the real mother and the good mother - the very fact that a woman gave birth means she must perform well, is supposed to have an obvious, immediate close bond to a child based on her maternal instinct (Park, 2013, p. 4). This emphasizing 
of the mother-child bond, its naturalization and romanticization, particularly in parenting guidebooks, makes it difficult to discuss it: who would dare to oppose biology and the unique experience of being pregnant, giving birth and connecting with a child? (Park, 2013, p. 5). As Park also suggests, such claims about the good mother are racialized and class-coded. I would also add that they are sexualized; it is obvious that a good mother is heterosexual; in Rich's terms, heterosexuality is downright compulsory. Systems of racial, sexual, class privilege thus produce and reproduce images, identities, characteristics of real, good mothers and award those obedient and following the rules with social and legal recognition; while oppressing, not recognizing and marginalizing ones who do not adjust to the scripts. This favouring and promotion of the nuclear, heteronormative and patriarchal family is conceptualized by Park a monomaternalism:

Monomaternalism, as an ideological doctrine, resides at the intersection of patriarchy (with its insistence that women bear responsibility for biological and social reproduction), heteronormativity (with its insistence that a woman must pair with a man, rather than other women, in order to raise children successfully), capitalism (in its conception of children as private property), and Eurocentrism (in its erasure of polymaternalism in other cultures and historical periods) (Parks, 2013, p. 7).

In spite of lack of acknowledgment as well as social and legal safety, nonheterosexual female couples reproduce, create and sustain relationships and kinships. It is worth paying closer attention, then, to how they were and are approached within such a heteronormative realm as the beliefs about one, real, good mother.

As Johnson argues, the research on lesbian mothers (it needs to be added that this applies to Western and particularly US studies) was conducted in three waves (Johnson, 2012, p. 45). The first, from the late ' 70 s, did studies on women who were in previous heterosexual relationships, had children and later entered same-sex relationship. The second wave, from the ' 80 s and ' 90 s, focused on women who planned parenthood together within their intimate relationships, usually considering the child's development and comparing the well-being of these children's with that of the children in heterosexual-headed families. The third-wave, which she claims is ongoing, is the one which studies lesbian-headed families themselves and their experiences (Johnson, 2012, pp. 45-46). The first two waves could be characterized by two predominant perspectives - assimilation and transformation.

Research conducted from the assimilation perspective was focused on the functioning of children in nonheterosexual-headed families in order to disassemble homophobic 
arguments that children in such families developed worse than in heterosexual-headed ones. These studies highlighted that LGBTQ families are just as heterosexual-headed families: normal and not threatening to society and the children's functioning. Their results proved that there were no significant differences in the psychological development of children. On the contrary, there were more similarities between them. Their importance for the legal recognition of LGBTQ families cannot be underestimated, however, one needs to take into account how such strategies strengthen heteronormativity and the claim that the heterosexual-headed family is the point of reference, the ideal to which LGBTQ families can (and should) aspire. When talking about approach to difference and sameness within the assimilation perspective, it is worth to take a closer look at the categorization of difference done by Clarke, regarding the psychological discourses towards lesbian-headed families. In her view, difference is conceptualized in research in four dimensions: "no difference, difference and deviance, difference and transformation, difference only because of oppression" (Clarke, 2002, pp. 210-222).

Thr first perspective, no difference, tries to prove that heterosexual and same-sex families are just the same and thereby challenge the homophobic views. The similarities are underscored both for parents and children. Clarke suggests that difference is evoked in such studies as a threat, while being similar or the same is presented as enticing. Thus, this perspective silences any differences that could appear within same-sex families. The second perspective, different and deviant, aims to emphasize the differences between non-heterosexual and heterosexual parents, certainly in favour of heteronormavity. These studies indicate nonheterosexual parents as pathological, promoting deviancy, doing harm to children, and thus posing threat to them. The approach called different and transformative states that lesbian mothers parent in a totally different way than heterosexual parents do; this carries the potential of social revolution and changing patriarchal patterns. The last approach, different only because of oppression, claims that the difference of lesbian parents is not there naturally it's constructed in an oppressive surrounding; once discrimination, stigmatization is overcome, it will turn out that LGBTQ families are just the same as heterosexual ones. As Clarke points out, such approach neglects completely the possibility that lesbian parents want to remain different and draw positive aspects from being outside the heteronormative world. Also, when talking about assimilative approach, it's worth noting that it neutralizes and silences sexuality of the partners raising a child, therefore adjusting to heteronormative pattern which does not recognize any sexuality other than 
heterosexual one. Moreover, the complexity of gender enactments within nonheterosexual women's relationships is also heavily criticized and not desirable.

The transformative approach to same-sex parenting, on the other hand, acknowledges the nonheterosexuality of parents and emphasizes the positive influence of same-sex families on the child. Within such a perspective, same-sex families are claimed to be characterised by more egalitarian partnerships, sharing equally the housework and pursuing more equal family practices in general (Dunne, 2000). Some researchers have expressed criticism towards such an approach, highlighting that it is utopian to argue that all samesex families challenge heteronormative patterns and always treat partners and children equally. In this regard, Ryan-Flood rightly points out to the expectation such ideal model causes; namely the pressure on nonheterosexual couples to be exceptionally good, not only better than their heterosexual counterparts but downright perfect (Ryan-Flood, 2009, p. 158). Such expectation, like the assimilationist approach, puts heterosexual families as the norm, as an ideal which should be achieved and even excelled. It sustains heteronormativity and again forces LGBTQ families to prove their value and justification for their right to have a family in the first place. In her study, respondents referred to such "extra eye" from society, following their moves and vigilant to catch any mistakes, which could prove that lesbians should not have children. Mothers are policed by others on a daily basis; they are unceasingly observed and disciplined to behave as a mother should.

The question which arises is how to think of and study same-sex families in order not to perpetuate such dichotomic approach? In Ryan-Flood's proposal, that can be done through situating experiences of lesbian mothers in the socio-political context and exploring how important the binaries are for their understanding of parenting, gender and sexuality. In this way, she argues that heteronormativity is not placed in the centre, as a benchmark. Her directions for future research underline that we still do not have much knowledge about the relational frameworks, choices and ideas of lesbian parents, since the studies so far have been focused on the child's well-being in a homophobic way to undermine lesbian mothers as legitimate parents. Paying attention to intersectionality, the intersecting mechanisms of ethnic, racial, class and other inequalities is another element that is missing in research on lesbian mothering (which has so far dealt predominantly white, middle-class and urban women, with few exceptions). Internal dynamics within nonheterosexual relationships - conflicts, separation, violence - have likewise not been explored exhaustively so far (probably mainly because of the assimilationist and transformative approach, aspiring to 
achieve and maintain the image of nonheterosexual partnership as one without any flaws). Besides these very specific directions for research, Ryan-Flood also points to the fact that women who decide together to have a child, enter a path of dismantling the heteronormative assumption of mothering with their every step to becoming mothers; from the very decision, through pregnancy, to parenting a child. When parenting, they enter multiplicity of public spaces, where they enact and negotiate their status: in their communities, schools, hospitals, playgrounds and other places (Ryan-Flood, 2009, p. 78). Through this queer(y)ing of "public" space, lesbian couples weaken the heteronormative spaces, deterritorialize and reterritorialize them. Besides the negotiation within public spaces, negotiations take place within the couples as regards choice of the "biological" parent, and the consequences of legal recognition of only one of the partners. Additionally, Ryan-Flood proposes to look in another way at heteronormativity, treated mostly as a monolith. What she suggests, is a conceptualization of heteronormativity as multiple heteronormativites, which in her view allows for cross-cultural analyses of heteronormative patterns, and for inclusion of various contexts when exploring experiences of nonheterosexual families. In this regard, it is also suggested to redefine the lesbian as a figure of the Other, to contextualize her in the cultural, political and social surroundings, which would demonstrate the "multifaceted nature of identity" and prove that "they are also individuals grounded in particular cultural norms and ideologies" (Ryan-Flood, 2009, p. 186), instead of conceptualizing the lesbian as being completely outside the norm or have her to her best to achieve heteronormative ideal. To explore this multiplicity, the intertwining privilege and marginalization must be acknowledged so as to allow for a more complex perception of subjectivity and to stop polarization between the heterosexual and the lesbian. As Park also suggests, this can be done through a deeper exploration of polymaternal families and putting in the centre of analysis how they queer intimacy through transformation of the mother-child bond, challenging time and space and the private-public binary (Park, 2013, p. 10). What needs to be analysed within such families is not only the relationship of mothers with a child and the child's functioning but also the relationship between the mothers themselves; as Gabb argues, sexuality within nonheterosexual women's couples is too often left in hiding, while visibility of sexuality within mothering relationship would be helpful for reconciliation with motherhood (Gabb, 2004, p. 124).

In order to analyse what is happening within polymaternal, lesbian, nonheterosexualheaded families, one needs to be aware of the above-mentioned monomaternal mechanisms 
of the real, good mother and the heteronormative mechanism of good/bad queers - as these are the contexts, spaces in which nonheterornormative identities, relationships and kinships are created and maintained. On the other hand, although it is important to spot and criticize normativities to which we succumb more or less consciously, at the same time it is crucial to remain cautious of the heteronormative discourses and practices being followed within such families and paying attention to how hetero/homo/normative these families actually are. What I would like to propose instead is to look into mothering as embodied experience, affective everyday practices, leaving aside the discussion of mothers as only oppressed or only liberated, but providing insight into their everyday work, giving them visibility, showing how mothering is transformed by families where there are two or more mothers. As Park points out:

The fact that many adoptive, divorce-extended, lesbian, and polygamous families may be shaped by normative values and practices does not mean that this is an essential property of such families. Nor does it mean that these are the only values embodied by such families (Park, 2013, p. 21).

Motherhood can therefore be thought of as experience, relational practice which is continuously de-centred, with values not necessarily relating only to heteronormative ones.

\section{Nomad mothers}

One of the ways, as I would like to argue, to explore families of nonheterosexual women without falling into the assimilationist and/or transformational trap is embracing the perspective of nomadic subjectivity, developed by Rosi Braidotti, which allows us to look at women who decide to mother together as ones who are always on the move, negotiating meanings and disrupting dominative spaces. As Braidotti argues, her project is interrelated with politics, as nomadic subjectivity addresses the necessity to denounce the mainstream and challenge its central position (Braidotti, 2011, p. 5), and look at power as both restrictive (potestas) and empowering (potentia) through a politics of location which enables higher awareness and self-reflexivity. This increase of awareness admittedly leads to defamiliarization, feeling of alienation and disintegration from the familiar, known:

A new critical distance is established between oneself and one's home grounds a sense of estrangement that is not painless, but rich in ethical rewards and increased 
understanding. The multiple differences of locations, which reflect the diversity of possible subject positions, therefore coalesce in the practice of disidentification from the familiar, estrangement from the already known. Like an epistemic detox cure, this practice marks the beginning of nomadic wisdom (Braidotti, 2011, p. 16).

The nomadic subject is in a continuous process of negotiating with power and transforming power relations; the body in this perspective is perceived as complex, carrying multiple functions, transforming energies, affects and imaginings, and this complexity is the lens which enables us to understand the multiplicity of our experiences. Nomadic subjectivity does not belong in and cannot be understood through binarisms and essentialisms, as it is not a monolith; a nomad desires to be made of changes. Nevertheless, it is not deprived of unity at all; a nomad develops and moves through patterns, makes connections but is not limited to one stable, fixed identity. What also needs to be highlighted is that being a nomad does not mean a painless experience. This experience includes contradictions, trauma, asymmetries; they are intrinsic elements of a nomad subjectivity. Nonheterosexual women having a child challenge the position of heteronormative motherhood as the only possible construct and defamiliarize the well-known norms of parenting and mothering. Nevertheless, while being distant towards stable patterns of motherhood, nomad mother subjects approach these patterns, relate to them and leave them for different spaces. Their families are spaces of flows of energy, affects present in everyday negotiations; territorializations, reterritorializations and deterritorializations of space.

To analyze this continuous becoming of nonheterosexual mothers, a process defined by Braidotti drawing from Deleuze and Guattari's framework, it is useful to take a closer look at their concept of rhizome and rhizoming analysis. They explain the rhizome structure by comparison to a tree - whereas a tree is a stable structure, the rhizome is a network with no centre, no specific direction - its roots grow in various directions and follow different patterns: "the rhizome connects any point to any other point, and its traits are not necessarily linked to traits of the same nature; it brings into play very different regimes of signs, and even nonsign states" (Deleuze \& Guattari, 1987, p. 25); this puts the rhizome in contrast to the tree, which represents a unity, stability, clear beginning and end. The authors compare the stability of the tree and movement of the rhizome, tree aims to be, whereas rhizome is focused on concurrences and adding and... and... and. The rhizome works through variation, expansion, capture. It does not have a beginning or an end - it is always "in the middle, between things, interbeing" (Deleuze \& Guattari, 1987, p. 25). Analyzing a rhizome lets us see 
the connections and places of fracture, the lines which establish becoming. Its aim is never to get to a stable point but to demonstrate the places of rupture, contradiction, instability of the categories, patterns, practices though to be stable and fixed. Deleuze and Guattari claim the rupture is important and it does not do damage to the rhizome, which can be broken, but it will rise and develop new connections from old broken ones, or will create new relations. Deterritorialization and reterritorialization are its features - the rhizome has its sections which organize, order and signify it; but it also goes in the direction of deterritorialization. Ruptures happen in places of deterritorialization, changes in the segments. Applying dichotomy to such movement is simply impossible, even if ruptures appear, new connections will be made continuously, lines will appear in unexpected places.

Deleuze and Guattari's framework helps us understand how subject is established when fixed, stable identity is absent, even rejected. Nonheterosexual mothers are not fixed once and for all and cannot be perceived as either/or: assimilating or resisting the heteronormative constructs; they are in a process, movement: "[...] they are part of those structures in a complicated multiplicity of unfoldings that result in fleeting images of fixity that can only be temporarily captured for study" (Hequembourg, 2007, p. 157).

Those images of fixity and stability are "molar" structures, which nevertheless are not stable, but are created by continuous movements within their elements; whereas "molecular" movements are fleeting. Nonheterosexual mothers find themselves within both molar and molecular structures, being in processes of deterritorialization and reterritorialization. Reterritorialization intends to search for unity and stability, whereas deterritorialization breaks stability (Hequembourg, 2007, p. 159). It might seem that these processes work against each other, but they do not. They belong to the same system, although their moves vary. Reterritorialization enables to stop for a moment and relate to stable constructs, whereas deterritorialization allows for going away and flows. Relations of power within these structures might not be mistakenly thought as inexistent for nonheterosexual mothers; heteronormativity shapes their experiences but they are also able to reterritorialize power constructs and reveal how unstable they are (Hequembourg, 2007, p. 161). Subjects, who de- and reterritorialize, are in an ongoing process of becoming, not driving to a specific end point, not moving between points $A$ and $Z$. It is:

a transformative process that results in new experiences without any ultimate end-goal. It is the experience of the process that constitutes a becoming rather than the beginning or end product upon which we most often focus our efforts. It requires a shift 
in focus to see "individuals" as masses of ever-fluctuating experience rather than fixed subjects who seek goals that result in new identities. The experiential process of becoming replaces the fixity of the subject (Hequembourg, 2007, p. 161).

It is not possible to break this experience apart and just identify the elements of the becoming. Becoming is always occurring, unfolding, never stagnant.

What happens within families where nonheteronormative mothering happens is what Deleuze and Guattari describe as a rhizome structure. Nonheteronormative mothers develop networks in which it is impossible to locate one clear centre. The relationships which they establish, contacts into which they enter have a rhizomatic form. They explore varieties of practices, expand familiar meanings and face ruptures, which nevertheless do not break them or destroy the whole family structure. Mothers enter many various spaces which might break their previous understanding and disturb their meanings, assumed probably as solid. What they do within such encounters is to redefine, make new, previously maybe unimaginable relations which form lines in various directions. These practices differ significantly from the binary resistance/assimilation, as being resistant means going outside, while assimilation is embracing the inside. Within the rhizome structure there is only the process of becoming, with no identifiable outside and inside, and imposing any inside/outside within such a structure would be just trying to adjust it to binarism.

\section{Nonheteronormative women with no mother passports or too many of them}

As Hequembourg argues, lesbian mothers

pose an ideal case study of becoming. They are always-already complex combinations of contradictions due to their contested position in our culture. Their experiences are shaped by very conservative and traditional ideologies about what constitutes a "family," while they also represent exciting promise for innovative change (Hequembourg, 2007, p. 163).

When we study their everyday behaviours, practices, we examine the molar structures of family, normativity, womanhood and nonheterosexuality as well as disruptions of these categories. We thus need to be aware that we leave the idea of unified, stable subject behind us. The nomad subjectivities are unstable processes. Of course, one might want 
to take a step back to ask: what does understanding of the nonheteronormative mother as a nomad give us, besides confusion, lack of clear rules and instructions to follow? After Braidotti, I wish to claim that relationship with new materialist concepts is indeed "a lifelong engagement with complexities and inner contradictions" (Dolphijn \& Tuin, 2012, p. 22). Embracing such an approach makes tensions, contradictions and feeling lost inseparable companions in following the lines - or rhizomes - within families. However, trying to conceptualize nonheteronormative mothers as subjects who are in a continuous search and who ceaselessly dismantle the known norms, gives us awareness of how careful and insightful we need to be when studying the subjectivities and rhizomes which nonheteronormative women develop/create/move within. These unstable subjectivities and movements let us map and better understand manipulations, power relations, negotiations of meanings and tensions which we observe and experience. How these negotiations work in practice has been studied by Gabb, among others, in her study on lesbian mothers negotiating time and space, being in-between and becoming in various spaces. As she argues, the division of space into family/sexuality spaces shows how lesbian mothers need to locate themselves (Gabb, 2005, p. 422) in relations with heteronormative authorities and institutions. As Braidotti's nomads, they navigate their identities, are in a "process of auto-poiesis or self-styling, which involves complex and continuous negotiations with dominant norms and values [...]" (Braidotti, 2013, p. 35). Within Gabb's study it might be observed how home, supposed to be a private, safe space, is not free of self-disciplining; therefore, we might observe how the ever so common public/private boundary is reworked and blurred as a result of new connections within.

"The nomad has no passport or has too many of them" (Braidotti, 2011, p. 64). Nonheteronormative mothers do not have any passport to the good/real mothers land. They do not want it and/or have too many of mothering passports when entering various lands, or spaces - hospitals, birthing schools, schools, homes, relatives' houses and many, many others. To find out what is happening in such spaces, what connections are made, what tensions appear, how negotiations with heteronormativity take place, one needs to agree to continuous becoming and withdraw from looking for one, safe, stable place; to prepare for the unexpected, sometimes probably seemingly chaotic and frustrating, experience of nomadic journeys. 


\section{Bibliography}

Braidotti, R. (2011). Nomadic subjects: Embodiment and sexual difference in contemporary feminist theory. New York: Columbia University Press.

Braidotti, R. (2013). The Posthuman. Cambridge: Polity.

Clarke, V. (2002). Sameness and difference in research on lesbian parenting. Journal of Community \& Applied Social Psychology, 12(3), 210-222. https://doi.org/10.1002/casp.673

Deleuze, G., \& Guattari, F. (1987). A thousand plateaus: Capitalism and schizophrenia. Minneapolis: University of Minnesota Press.

Dolphijn, R., \& Tuin, I. V. (2012). New materialism: Interviews \& cartographies. Ann Arbor: Open Humanities Press.

Dunne, G. A. (2000). Opting into motherhood: Lesbians blurring the boundaries and transforming the meaning of parenthood and kinship. Gender \& Society, 14(1), 11-35. https://doi. org/10.1177/089124300014001003

Gabb J. (2004). Imagining the queer lesbian family. In A. O'Reilly (Ed.), Mother outlaws (pp. 123-130). Toronto: Canadian Scholars' Press.

Gabb, J. (2005). Locating lesbian parent families: Everyday negotiations of lesbian motherhood in Britain. Gender, Place \& Culture, 12(4), 419-432. https://doi.org/10.1080/09663690500356768 Hequembourg, A. L. (2007). Becoming lesbian mothers. Journal of Homosexuality, 53(3), 153-180. https://doi.org/10.1300/J082v53n03_09

Johnson, S. M. (2012). Lesbian mothers and their children: The third wave. Journal of Lesbian Studies, 16(1), 45-53. https://doi.org/10.1080/10894160.2011.557642

O'Reilly, A. (2004). Introduction. In A. O'Reilly (Ed.), From motherhood to mothering: The legacy of Adrienne Rich's "Of woman born" (pp. 1-23). Albany: State University of New York Press.

Park, S. M. (2013). Mothering queerly, queering motherhood: Resisting monomaternalism in adoptive, lesbian, blended, and polygamous families. Albany: State University of New York Press.

Rich, A. (1976). Of woman born: Motherhood as experience and institution. New York: Norton.

Ryan-Flood, R. (2009). Lesbian motherhood: Gender, families and sexual citizenship. Basingstoke: Palgrave Macmillan.

Springgay, S., \& Freedman, D. (2012). Mothering a bodied curriculum: Emplacement, desire, affect. Toronto: University of Toronto Press.

Thompson, J. (2002). Mommy queerest: Contemporary rhetorics of lesbian maternal identity. Amherst: University of Massachusetts Press. 


\title{
From assimilation, through transformation to studies within relationships: Understandings of nonheteronormative motherhood and ways forward
}

Nonheteronormative motherhood has been explored in many studies so far, aiming to explore the strategies of women who develop and maintain kinships in patriarchal settings. So far, the approaches to motherhood beyond hetero/normativity have been mostly focused on considering either assimilationist strategies or transformational potential of families of choice. In this article I would like to propose one of the possible ways enabling us to avoid these approaches. I argue that Rosi Braidotti's framework of nomadic subjectivity and considering nonheteronormative motherhood as embodied experience might provide us with a lens through which we can look at mothering as de-centred, continuous becoming on a daily basis.

\section{Keywords:}

lesbian motherhood, same-sex relationships, nonheteronormative motherhood, nomadic subjectivities

\section{Od asymilacji, poprzez transformację do studiów w ramach relacji: rozumienia nieheteronormatywnego macierzyństwa i drogi na przyszłość}

\begin{abstract}
Nieheteronormatywne macierzyństwo było do tej pory zgłębiane w wielu badaniach, mających na celu poznanie strategii kobiet, które tworzą i podtrzymują więzi w patriarchalnym otoczeniu. Dotychczas podejścia do macierzyństwa poza hetero/normatywnością były skupione przede wszystkim na rozważaniu asymilacyjnych strategii bądź transformatywnego potencjału rodzin z wyboru. W niniejszym artykule chciałabym zaproponować jedno z podejść umożliwiające uniknięcie wcześniejszych strategii. Dowodzę, że koncepcja nomadycznej tożsamości Rosi Braidotti oraz rozważanie nieheteronormatywnego macierzyństwa jako ucieleśnionego doświadczenia może zapewnić nam soczewkę, dzięki której możemy spojrzeć na macierzyństwo jako zdecentralizowany, ciągły proces codziennego stawania się matką.
\end{abstract}

\section{Słowa kluczowe:}

lesbijskie macierzyństwo, relacje jednopłciowe, nieheteronormatywne macierzyństwo, nomadyczne tożsamości

\section{Citation:}

Kot, M. (2017). From assimilation, through transformation, to studies within relationships: Understandings of nonheteronormative motherhood and ways forward. Adeptus, 2017(9). https://doi.org/10.11649/a.1431 